between successive cases within a household never exceeded seven days. The household was therefore more favourable than the community to the spread of H.K. variant, the risk to household contacts of the first case being increased fourfold. It is natural to infer that subsequent cases, all of which occurred within 10 days of the first were caused by person-toperson spread. If so, a relatively constant serial interval between successive cases should be present, representing the duration of the human-host parasite reproductive cycle (HopeSimpson, 1948). In this outbreak there are unfortunately too few household case-intervals to provide this decisive evidence.

Many institutional epidemics of H.K. influenza have been recorded in which $30-50 \%$ of inmates were affected. The overall attack rate in our affected households was also about $40 \%$.

The day school in Britain is important in disseminating many viruses, the day scholar being commonly the person to introduce the virus into the household. In this general practice population during the 1951 influenza A epidemic, it appeared (Hope-Simpson, 1951) that whereas day scholars had been the most important group for measles they had played no special part in introducing influenza into the households. The present investigation, examining virus-positive cases, once again found that schoolchildren were no more likely than anyone else to be the first cases in the household, and that children below school age were even less likely (Table VIII).

I would like to thank the following: the Public Health Laboratory Service and the Medical Research Council for providing facilities for the work; Dr. P. G. Higgins and the Cirencester Public Health Virological Laboratory for collaboration; Dr. Marguerite S. Pereira for serological typing of influenza viruses, my partner, Dr. E. J. Guest, and Dr. P. F. Cassidy for helping with recording and taking of specimens; my own staff for endless help and tolerance and my patients for cheerful co-operation; Dr. Allan Withnell and other members of the Gloucestershire County Council Health Department, especially Miss E. Short and Miss D. Little, for cooperation in the household study; and Sir James Howie, Dr. T Pollock, Dr. D. Miller, Dr. G. C. Schild, and Dr. P. G. Higgins for most helpful criticism of this paper.

\section{REFERENCES}

Coleman, M. T., Dowdle, W. R., Pereira, H. G., Schild, G. C., and Chang, W. K. (1968). Lancet, 2, 1384.

Higgins, P. G., Boston, D. G., and Ellis, E. M. (1964). Monthly Bulletin of the Ministry of Health and the Public Health Laboratory

Hope-Simpson, R. E. (1948). Lancet, 2, 755.

Hope-Simpson, R. E. (1951). Proceedings of the Royal Society of Medicine, 44, 798.
cimp.

Medical fournal of Australia, 1968, 2, 962.

Paniker, C. K. J. (1968). Fournal of General Virology, 2, 385.

Pereira, H. G. (1969). Progress in Medical Virology, 11, 46.

\title{
Peritoneal Dialysis for Pulmonary Oedema After Acute Myocardial Infarction
}

\author{
M. P. CHOPRA, ${ }^{*}$ M.B., B.S. ; R. B. GULATI, $\uparrow$ M.D. ; R. W. PORTAL, $\ddagger$ M.D., M.R.C.P. \\ CLIVE P. ABER, $\ddagger$ B.SC., M.D., M.R.C.P.
}

\begin{abstract}
Cummary: Four patients with intractable pulmonary oedema after acute myocardial infarction were treated with peritoneal dialysis. A negative fluid balance was rapidly achieved in three patients, two of whom ultimately survived. The fourth patient, who had complete heart block at the beginning of dialysis, showed initial clinical improvement with restoration of sinus rhythm despite failure to extract fluid.
\end{abstract}

\section{Introduction}

Resolution of chronic intractable congestive heart failure in adults and pulmonary oedema superimposed on refractory heart failure in infants and children has been achieved by the use of peritoneal dialysis (Schneierson, 1949; Bertrand and Guerin, 1961; Nora et al., 1966; Mailloux et al., 1967; Cairns et al., 1968). It therefore seemed reasonable to use this technique to treat pulmonary oedema after acute myocardial infarction when more conventional diuretic measures had failed to produce a satisfactory response. Such patients have a poor prognosis owing to the complications that arise from the associated severe anoxia, hypotension, and metabolic acidosis (Rosenbaum and Levine, 1941; Peel et al., 1962; MacKenzie, 1964; McNicol et al., 1965). This paper describes our initial experience with this method of treating pulmonary oedema after acute myocardial infarction.

\footnotetext{
*Research Assistant.

tSenior House Officer.

$\neq$ Consultant Physician.

Department of Cardiology, Kingston General Hospital, Hull.

SPresent address: Department of Medicine, B. J. Medical College and Sassoon General Hospitals, Poona, India.
}

Peritoneal dialysis was performed on four men with proved acute myocardial infarction. The diagnosis was based on a typical clinical history with characteristic electrocardiographic changes (World Health Organization, 1959) and/or a significant rise in enzymes (aspartate aminotransferase and $\alpha$-hydroxybutyrate dehydrogenase). The clinical details are summarized in Table I.

Blood urea and serum electrolyte studies were carried out before and after dialysis. Serial arterial blood gas and acidbase studies were made on two patients (Table II). Predialysis and post-dialysis portable anteroposterior chest radiographs, taken at a distance of $5 \mathrm{ft}$. $(1.5 \mathrm{~m}$.), were assessed for evidence of cardiac enlargement, pulmonary venous hypertension, pleural effusions, and pulmonary oedema with a modification of the method of Tattersfield et al. (1969). Cardiac size was evaluated from the cardiothoracic ratio-namely, ratio less than $50 \%=0$ mark; $51 \%$ to $60 \%$ $=1$ mark; $61 \%$ or greater $=2$ marks. Pulmonary venous hypertension was assessed by examination of the chest radiographs for (a) upper lobe pulmonary venous congestion (no congestion $=0$ mark; mild congestion $=1$ mark; marked congestion $=2$ marks), and (b) evidence of septal lines (no septal lines $=0$ mark; septal lines $=1$ mark). A pleural effusion, if present, scored 1 mark. Pulmonary oedema was evaluated on the basis of its presence ( 1 mark) or absence ( 0 mark) in the upper, middle, and lower zones (assessed separately) of each lung field. This gave a possible maximum total of 6 marks and, though arbitrary, enabled us to record changes in the degree of oedema. Accurate measurement of the width of the superior mediastinum proved impossible; Tattersfield et al. (1969) also found this measurement unreliable. 
TABLE I.-Clinical Details

\begin{tabular}{|c|c|c|c|c|c|c|}
\hline Case No. & & Age & Diagnosis & $\begin{array}{l}\text { Interval between Infarct } \\
\text { and Pulmonary Oedema }\end{array}$ & $\begin{array}{l}\text { Diuretics given before } \\
\text { Peritoneal Dialysis }\end{array}$ & Outcome \\
\hline $\begin{array}{ll}1 & \cdots \\
2 & \cdots \\
3 & \cdots \\
4 & \ldots\end{array}$ & $\begin{array}{l}\cdots \\
\cdots \\
\cdots \\
\cdots\end{array}$ & $\begin{array}{l}60 \\
46 \\
54 \\
65\end{array}$ & $\begin{array}{l}\text { Acute anterior myocardial infarc- } \\
\text { tion. Diabetes mellitus } \\
\text { Acute posterior myocardial infarc- } \\
\text { tion } \\
\text { Acute anterior myocardial infarc- } \\
\text { tion. Diabetes mellitus } \\
\text { Acute posterior myocardial infarc- } \\
\text { tion on admission. Later de- } \\
\text { veloped anterior myocardial } \\
\text { infarction }\end{array}$ & $\begin{array}{c}72 \text { hours } \\
2 \text { hours } \\
14 \text { hours } \\
\text { Immediately after second } \\
\text { infarction }\end{array}$ & $\begin{array}{l}\text { Frusemide } 80-120 \mathrm{mg} \text {. and ethacrynic } \\
\text { acid } 100 \mathrm{mg} \text {. i.v. daily for } 4 \text { days } \\
\text { Frusemide } 80-200 \text { mg. and ethacrynic } \\
\text { acid } 100 \mathrm{mg} \text {. i.v. daily for } 3 \text { days } \\
\text { Frusemide } 80 \text { mg. and ethacrynic } \\
\text { acid } 50 \mathrm{mg} \text {. i.v. on day of dialysis } \\
\text { Frusemide } 80-200 \text { mg. and ethacrynic } \\
\text { acid } 50 \mathrm{mg} \text {. i.v. daily for } 4 \text { days }\end{array}$ & $\begin{array}{c}\text { Survived } \\
\text { Survived } \\
\text { Died in congestive cardiac failure } \\
33 \text { days after peritoneal dialysis } \\
\text { Died suddenly } 16 \text { days after } \\
\text { peritoneal dialysis }\end{array}$ \\
\hline
\end{tabular}

TABLE II.-Biochemical, Blood Gas and Acid-base Details of Four Patients Before and After Dialysis

\begin{tabular}{|c|c|c|c|c|c|c|c|c|c|c|c|}
\hline \multirow{3}{*}{\multicolumn{2}{|c|}{ Case No. }} & & \multicolumn{5}{|c|}{ Blood Urea and Serum Electrolytes } & \multicolumn{4}{|c|}{ Arterial $p \mathrm{H}$ and Blood Gas Status } \\
\hline & & & \multirow{2}{*}{$\begin{array}{c}\text { Blood } \\
\text { Urea } \\
\text { (mg./100 ml.) }\end{array}$} & $\mathrm{Na}$ & $\mathbf{K}$ & $\mathrm{Cl}$ & $\mathrm{HCO}_{3}$ & \multirow{2}{*}{$p \mathbf{H}$} & \multirow{2}{*}{$\underset{\left(\mathrm{mm} . \mathrm{H}_{\mathbf{g}}\right)}{\mathrm{PCO}_{\mathbf{3}}}$} & \multirow{2}{*}{$\begin{array}{c}\mathrm{Po}_{\mathbf{2}} \\
\left(\mathrm{mm} . \mathbf{H}_{\mathbf{g}}\right)\end{array}$} & \multirow{2}{*}{$\begin{array}{c}\text { Base } \\
\text { Deviation } \\
\text { (mEq/l.) }\end{array}$} \\
\hline & & & & \multicolumn{4}{|c|}{$\mathrm{mEq} / \mathbf{l}$. } & & & & \\
\hline $\begin{array}{l}1 \\
2 \\
3 \\
4\end{array}$ & $\begin{array}{l}\cdots \\
\cdots \\
\cdots \\
\cdots\end{array}$ & $\begin{array}{l}\cdots \\
\cdots \\
\cdots \\
\cdots\end{array}$ & $\begin{array}{lr}\text { A. } & 76 \\
\text { B. } & 97 \\
\text { A. } & 108 \\
\text { B. } & 126 \\
\text { A. } & 25 \\
\text { B. } & 44 \\
\text { A. } & 184 \\
\text { B. } & 162\end{array}$ & $\begin{array}{l}132 \\
152 \\
133 \\
141 \\
129 \\
139 \\
130 \\
133\end{array}$ & $\begin{array}{l}4 \cdot 8 \\
4 \cdot 4 \\
4 \cdot 2 \\
4 \cdot 6 \\
5 \cdot 6 \\
4 \cdot 3 \\
6 \cdot 0 \\
4 \cdot 6\end{array}$ & $\begin{array}{r}87 \\
103 \\
95 \\
100 \\
94 \\
95 \\
90 \\
90\end{array}$ & $\begin{array}{l}18 \\
25 \\
21 \\
27 \\
18 \\
28 \\
22 \\
21\end{array}$ & $\begin{array}{l}7.27 \\
7.52 \\
7.45 \\
7.51\end{array}$ & $\begin{array}{l}28 \\
37 \\
26 \\
36\end{array}$ & $\begin{array}{l}61^{*} \\
76^{*} \\
65 \\
66\end{array}$ & $\begin{array}{r}13 \\
+6 \\
+\quad 3 \\
+\quad 6\end{array}$ \\
\hline
\end{tabular}

$A=$ Before dialysis. $B=$ After dialysis.

A $=$ Before dialysis. B $=$ After dialysis.
$=$ Receiving oxygen by M.C. mask (6 litres/minute).

Peritoneal dialysis was performed under aseptic conditions with the Trocath Peritoneal Dialysis Catheter (McGaw Laboratories). Three patients were dialysed in a cardiac monitoring unit and the fourth in a general medical ward. A vesical catheter was introduced before dialysis and left in situ until completion of the dialysis programme. Dialaflex No. 62 (Allen \& Hanburys Ltd.) was used as the hypertonic dialysing fluid (dextrose B.P. $6.36 \%$, sodium lactate B.P.C. $0.5 \%$, sodium chloride $0.56 \%$, calcium chloride B.P. $0.039 \%$, and magnesium chloride B.P.C. $0.015 \%$ ). When the initial serum potassium was normal, $4 \mathrm{mEq}$ of potassium chloride was added to each litre of fluid, which also contained 500 units of heparin. Each litre of dialysing fluid was run in over 10 minutes and allowed to remain in the peritoneal cavity for a further 10 minutes before being siphoned back by gravity. Each exchange was completed in 30 to 45 minutes. Details of the four dialyses are shown in Table III.

TABLe III.-Details of Peritoneal Dialyses

\begin{tabular}{|c|c|c|c|c|}
\hline Case No. & $\begin{array}{c}\text { Interval between } \\
\text { Diagnosis of } \\
\text { Pulmonary Oedema } \\
\text { and Dialysis }\end{array}$ & $\begin{array}{c}\text { Duration of } \\
\text { Dialysis }\end{array}$ & $\begin{array}{c}\begin{array}{c}\text { No. of } \\
\text { Exchanges }\end{array}\end{array}$ & $\begin{array}{l}\text { Fluid Extracted } \\
\text { by Peritoneal } \\
\text { Dialysis (ml.) }\end{array}$ \\
\hline $\begin{array}{ll}1 & \cdots \\
2 & \cdots \\
3 & \cdots \\
4 & \cdots\end{array}$ & $\begin{array}{l}7 \text { days } \\
72 \text { hours } \\
41 \text { hours } \\
5 \text { days }\end{array}$ & $\begin{array}{l}18 \text { hours } \\
71 \text { hours } \\
51 \text { hours } \\
10 \text { hours }\end{array}$ & $\begin{array}{r}25 \\
12 \\
10 \\
9\end{array}$ & $\begin{array}{r}7,675 \\
2,500 \\
1,470 \\
120\end{array}$ \\
\hline
\end{tabular}

\section{Case 1}

A man aged 60 was admitted to the Hull Royal Infirmary on 16 November 1968 after an acute anterior myocardial infarction on 13 November. On admission there was evidence of left heart failure with sinus tachycardia $(110 / \mathrm{min}$.), a blood pressure of $110 / 80$ $\mathrm{mm}$. Hg, and a gallop rhythm. The E.C.G. showed anterior wall necrosis and the chest radiograph pulmonary oedema. He was also found to be diabetic. By 18 November, after diuretic therapy, the pulmonary oedema had cleared. On 26 November the clinical condition deteriorated and pulmonary oedema returned. Despite rapid digitalization and increased intravenous diuretics (frusemide and ethacrynic acid-Table I), the pulmonary oedema persisted and by 3 December there was also evidence of azotaemia (blood urea of $76 \mathrm{mg} . / 100 \mathrm{ml}$.) and diabetic acidosis.
Peritoneal dialysis was begun and continued for $18 \frac{1}{4}$ hours, by which time there had been considerable clinical and radiographic improvement with extraction of $7,675 \mathrm{ml}$. of fluid. Six days later the pulmonary oedema had almost resolved (Table IV, Fig. 1) and oral diuretics were producing a satisfactory diuresis. He left hospital on 2 January 1969 on a maintenance dose of digoxin, oral diuretics, and potassium supplements.

TABLE IV.-Assessment of Chest Radiographs Before and After Peritoneal Dialysis

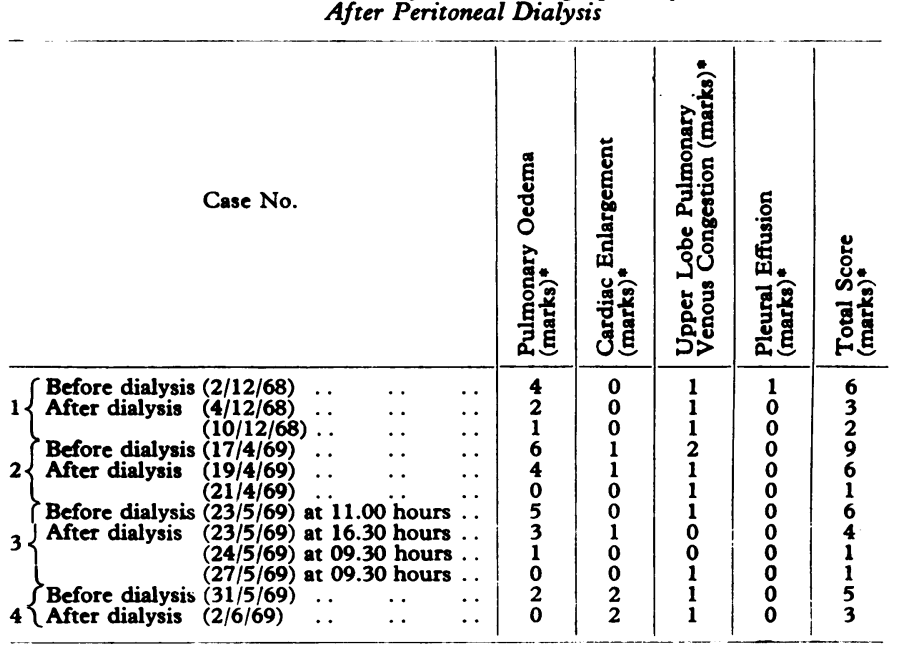

* For explanation of the score see text.

\section{Case 2}

A man aged 46 was admitted from the casualty department of the Hull Royal Infirmary to the cardiac monitoring unit, Kingston General Hospital, on 15 April 1969 two hours after acute myocardial infarction. During interhospital transfer he "collapsed" and vomited. On arrival in the unit he was cyanosed and hypotensive (systolic blood pressure $70 \mathrm{~mm}$. $\mathrm{Hg}$ ) and in left heart failure. The pulse rate was 68 per minute. The E.C.G. showed sinus rhythm and acute posterior myocardial infarction. The chest radiograph showed pulmonary oedema. Despite intensive therapy, including the administration of oxygen (6 litres/minute by M.C. mask), repeated intravenous diuretics (frusemide and ethacrynic acid- 


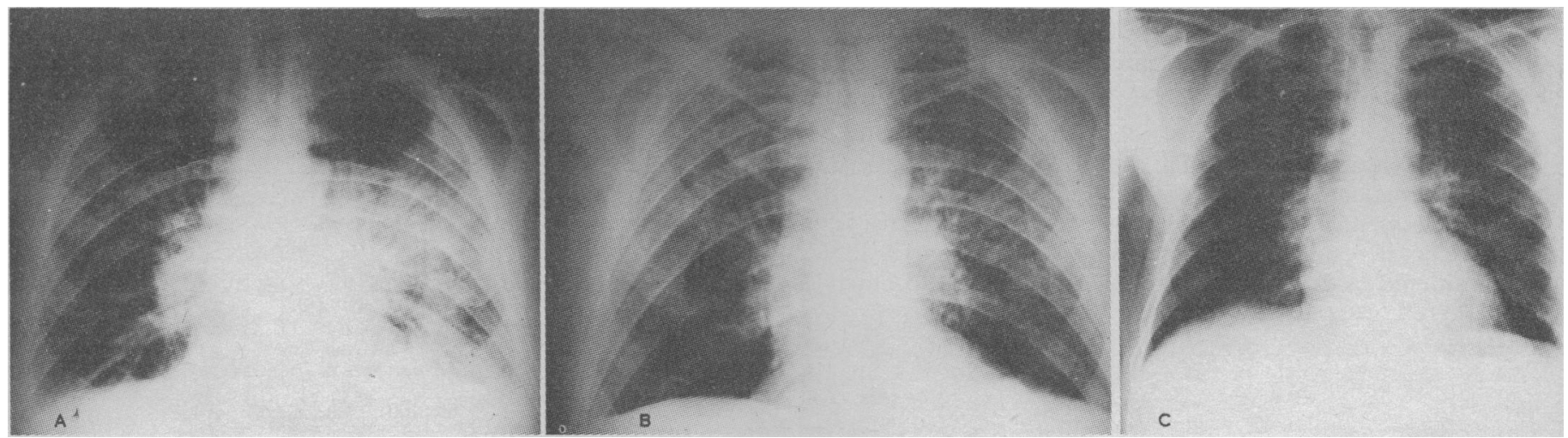

Fig. 1.-Case 1. Chest radiographs $(a)$ before, $(b)$ immediately after, and $(c)$ six days after peritoneal dialysis, showing gradual resolution of pulmonary

Table I), digitalization (using ouabain), and medical venesection during the first 72 hours after admission, he remained critically ill with persistent cyanosis, hypotension, and extensive pulmonary oedema. Furthermore, during this period the blood urea had risen from 59 to $108 \mathrm{mg} . / 100 \mathrm{ml}$.

Peritoneal dialysis was begun on 18 April and continued for seven and three-quarter hours, during which $2,500 \mathrm{ml}$. of fluid was extracted (Table III). Within three hours of beginning dialysis there was subjective improvement, and by 21 April the pulmonary oedema had cleared completely (Table IV). His subsequent progress was very satisfactory and he left hospital four weeks after admission, at which time he was receiving digoxin, oral diuretics, and potassium supplements.

\section{Case 3}

A 54-year-old diabetic was admitted to the cardiac monitoring unit 14 hours after acute myocardial infarction. On arrival at 09.55 hours on 23 May 1969 he was hypotensive (blood pressure 90/70 $\mathrm{mm} . \mathrm{Hg}$ ) and in left heart failure. The pulse rate was 96 per minute. The E.C.G. showed right bundle-branch block with anterior myocardial infarction. A chest radiograph showed pulmonary oedema. The arterial $\mathrm{pH}$ and blood gas values and blood urea and serum electrolytes are shown in Table II. The blood sugar was $200 \mathrm{mg} . / 100 \mathrm{ml}$.

At 12.50 hours on 23 May he developed supraventricular tachycardia. Despite correction of the base deficit this arrhythmia persisted and his clinical status deteriorated rapidly. Sinus rhythm returned immediately after a $50 \mathrm{mg}$. intravenous bolus of lignocaine hydrochloride. Since by this time there had been no response to intravenous diuretics (frusemide and ethacrynic acidTable I) and digitalization (ouabain), peritoneal dialysis was begun and continued for five and a half hours, during which $1,470 \mathrm{ml}$. of fluid was extracted (Table III). His clinical condition improved rapidly and by 09.30 hours on 27 May the pulmonary oedema had disappeared (Table IV) and he had experienced no further arrhythmias. At the end of the dialysis programme (21.30 hours on 23 May) the arterial $p H$ and blood gas values were: $p H 7.52$, $\mathrm{PCO}_{2} 37 \mathrm{~mm}$. $\mathrm{Hg}, \mathrm{Po}_{2} 76 \mathrm{~mm}$. $\mathrm{Hg}$, base excess $+6 \mathrm{mEq} / 1$. (on 6 litres/minute oxygen by M.C. mask) (Table II).

His subsequent progress was punctuated by further attacks of acute left ventricular failure, and on 27 June, 33 days after completing his peritoneal dialysis, he died. Necropsy showed necrosis of the anterior and posterior walls of the left ventricle and septum.

\section{Case 4}

A man aged 65 was admitted to the cardiac monitoring unit six hours after acute myocardial infarction. On arrival (13 May 1969) there seemed to be no reason for undue clinical concern. The E.C.G. showed acute posterior myocardial infarction with occasional junctional ectopic beats. Thirty-six hours later he developed a transient Wenckebach phenomenon and later 2:1 atrioventricular block, but his clinical status remained good.

At 00.30 hours on 26 May he experienced further acute prolonged ischaemic myocardial pain and developed left ventricular failure. The E.C.G. showed fresh anterior myocardial necrosis.
At this stage the arterial $p H$ and blood gas values were: $p H$ $7.22, \mathrm{PCO}_{2} 33 \mathrm{~mm}$. $\mathrm{Hg}, \mathrm{Po}_{2} 78 \mathrm{~mm}$. $\mathrm{Hg}$, with a base deficit of $-13 \mathrm{mEq} / 1$. (on 6 litres/minute oxygen by nasal catheter). The base deficit was immediately corrected with intravenous $8.4 \%$ sodium bicarbonate. After rapid digitalization (intravenous ouabain) and the administration of intravenous frusemide, there was considerable improvement with a satisfactory diuresis. Six hours later (06.30 hours on $26 \mathrm{May}$ ) he developed complete heart block with recurrent Stokes-Adams syncope due to prolonged asystole. Successful resuscitation was achieved by the insertion of a transvenous pacing catheter into the right ventricle. Despite continuous endocardial pacing for five days and the administration of intravenous diuretics (frusemide and ethacrynic acid-Table I), the urinary output remained poor and the chest radiograph continued to show moderately severe pulmonary oedema and considerable cardiac enlargement (Table IV).

Peritoneal dialysis was begun and continued for 10 hours. A significant negative fluid balance was not achieved but sinus rhythm returned two hours after beginning dialysis. Within 36 hours of completing dialysis the pulmonary oedema had disappeared. A satisfactory diuresis was then maintained with oral diuretics. His subsequent progress was very satisfactory until 16 days after dialysis when he developed unheralded cardiac arrest on the ward and attempts at resuscitation were unsuccessful. Necropsy confirmed both anterior and posterior myocardial infarction.

\section{Discussion}

The use of peritoneal dialysis in cardiac failure is a wellestablished procedure, but we have found no reference to its use after acute myocardial infarction. In the past five years intensive coronary care has considerably reduced the mortality from acute infarction, the figure for most established units now lying between $14 \%$ and $20 \%$. The chance of survival after primary ventricular fibrillation is high, and when infarction is complicated by heart block the prognosis may be improved by the use of artificial pacing (Paulk and Hurst, 1966; Scott et al., 1967; Chatterjee et al., 1969). Persistent pulmonary oedema carries a poor prognosis, for in these patients the incidence of arrhythmias is high and it is often impossible to obtain a rise in the arterial oxygen tension without a satisfactory diuresis.

Peritoneal dialysis not only provides a relatively safe, efficient, and rapid means of establishing a negative fluid balance but corrects any metabolic imbalance without loading the patient with intravenous fluids. This may in part explain why three of our four patients (Cases 1, 2, and 3) improved before the complete disappearance of their pulmonary oedema, despite the fact that the blood urea and serum sodium rose rather than fell by the completion of the dialysis. Presumably this was the result of removal of water from expanded intravenous and extracellular spaces. In Case 4, where a negative fluid balance was not achieved, the clinical improvement may in part have been related to the return of normal atrioventricular conduction, but it is impossible to say whether this was attributable to the dialysis. Another finding

dod


was that a satisfactory response to oral and parenteral diuretics occurred after dialysis, as has been reported by Mailloux et al. (1967) after using this technique in intractable chronic congestive heart failure.

So far our experience of peritoneal dialysis for pulmonary oedema after acute myocardial infarction is small, because nearly all patients respond to oral or intravenous diuretics. Nevertheless, since we believe that two of the four patients survived as a result of the procedure, we feel that it should be considered as an emergency measure when this problem is encountered.

We are grateful to Dr. A. E. Pratt, Consultant Radiologist, Kingston General Hospital, for his help in evaluating the chest radiographs.
REFERENCES

Bertrand, E., and Guerin, J. (1961). Médecine Tropicale, 21, 603.

Cairns, K. B., Porter, G. A., Kloster, F. E., Bristow, J. D., and Griswold, H. E. (1968). American Heart fournal, 76, 227.

Chatterjee, K., Harris, A., and Leatham, A. (1969). Lancet, 2, 1061.

MacKenzie, G. J., et al. (1964). Lancet, 2, 825.

McNicol, M. W., et al. (1965). British Medical fournal, 2, 1270.

Mailloux, L. U., et al. (1967). Fournal of the American Medical Association, 199, 873.

Nora, J. J., Trygstad, C. W., Mangos, J. A., 'Sibbons, J. E., and Jegier, W. (1966). Fournal of Pediatrics, 68, 693.

Paulk, E. A., jun., and Hurst, J. W. (1966). American fournal of Cardiology, 17, 695 .

Peel, A. A. F., Semple, T., Wang, I., Lancaster W. M., and Dall, J. L. G. (1962). British Heart fournal, 24, 745.

Rosenbaum, F. F., and Levine, S. A. (1941). Archives of Internal Medicine, $68,913$.

Schneierson, S. J. (1949). American fournal of the Medical Sciences, 218, 76 .

Scott, M. E., Geddes, J. S., Patterson, G. C., Adgey, A. A. J., and Pantridge, J. F. (1967). Lancet, 2, 1382.

Tattersfield, A. E., McNicol, M. W., Shawdon, H., and Rolfe, D. (1969). British Medical fournal, $3,332$.

World Health Organization (1959). World Health Organization. Technical Report Series, No. 168.

\title{
Vancomycin for Staphylococcal Shunt Site Infections in Patients on Regular Haemodialysis
}

\author{
SUSANNAH EYKYN, ${ }^{*}$ M.B. ; IAN PHILLIPS, $†$ M.D., M.R.C.PATH. ; JOHN EVANS, $\ddagger$ M.B.
}

\begin{abstract}
Cummary: Six anuric patients with Scribner shunt site infections were treated by intermittent infusion of vancomycin into the shunt, and a satisfactory clinical response was obtained in five. Serum levels of the antibiotic were estimated frequently. From estimating serum levels and the minimum inhibitory concentrations of vancomycin for a range of hospital staphylococci a dose of 1g. vancomycin every seven days is recommended as a suitable schedule for treating staphylococcal infection in this situation.
\end{abstract}

\section{Introduction}

Vancomycin was first isolated in 1956 from Streptomyces orientalis and shown to be highly active in vitro against Gram-positive organisms. It is bactericidal in concentrations not much greater than those needed to achieve bacteriostasis, natural resistance to the drug is rare, and acquired resistance has not been reported. Vancomycin has, however, been of only limited clinical use, firstly because it must be given by intravenous infusion for systemic effect, secondly because it is ototoxic at excessively high serum levels, and, finally, because there are other non-toxic drugs with equally good bactericidal activity against staphylococci and streptococci.

Great care is needed in the use of vancomycin when renal function is impaired; Dutton and Elmes (1959) found severe loss of auditory acuity in four, possibly five, of nine patients after treatment with vancomycin, all of whom had some degree of renal failure. Geraci et al. (1958) reported perceptive deafness occurring in two patients, one of whom had renal insufficiency, with serum vancomycin levels of $80-100$ $\mu \mathrm{g} . / \mathrm{ml}$. The critical serum level below which eighth nerve toxicity does not occur is not known.

When shunt site infections occur in patients on haemodialysis the organisms isolated are very often staphylococci, either coagulase-positive or coagulase-negative.

\footnotetext{
* Lecturer, Department of Clinical Microbiology.

+ Senior Lecturer, Department of Clinical Microbiology.

$¥$ Senior House Officer, Renal Unit, St. Thomas's Hospital, London S.E.1.
}

Prompt effective treatment is essential to save the shunt and to avoid septicaemia. Ideally the antibiotic selected should be bactericidal, should have good antistaphylococcal activity, and should not be largely removed by haemodialysis, so that it can be given by intermittent infusion into the shunt. In these patients repeated intramuscular injections are best avoided because of the need for heparinization, and oral antibiotics often lead to nausea and vomiting. Vancomycin is particularly suitable for treatment of shunt site infections: it is bactericidal, highly active against staphylococci, is normally almost entirely excreted by the kidney, and is not removed by dialysis (Lindholm and Murray, 1966). . Intermittent administration will therefore produce therapeutic levels in anuric patients which persist for some time.

\section{Patients and Methods}

Sensitivity of Staphylococci to Vancomycin.-Minimum inhibitory concentrations of vancomycin were determined for a range of hospital staphylococci, D.S.T. agar (Oxoid) with an inoculum of $0.02 \mathrm{ml}$. of a broth culture containing about $10^{4}$ organisms per ml. being used. The results were read after 24 hours' incubation. The staphylococci tested included both coagulase-positive and coagulase-negative strains; they were selected to include a range of sensitivities to other antibiotics and many showed multiple resistance.

Patients.-Six patients (four men, two women) aged 19-32 years were treated with vancomycin for shunt site infections. All were having regular haemodialysis for end-stage renal failure and two were anephric. Swabs for bacteriobogical examination were taken from the shunt site of each patient before vancomycin was given and in three cases the minimum inhibitory concentration of vancomycin was determined for the organism isolated. Further cultures were taken from some patients during treatment. The initial dose of vancomycin was $1 \mathrm{~g}$. in four patients and $0.5 \mathrm{~g}$. in two; these doses were repeated when the serum level of the drug fell below a therapeutic level. The antibiotic was given by slow infusion into the venous line during the final 30 to 60 minutes of dialysis. Three of the six patients were also treated with intermittent 